\title{
Lexical Cycles in Modern Russian
}

\section{Kharitonchik Zinaida Andreevna ${ }^{1}$}

\author{
Professor, Minsk State Linguistic University
}

Minsk, Belarus.

\section{Karbachova Tatiana Valerievna ${ }^{2}$}

Postgraduate of the general linguistics department, Minsk State Linguistic University, Minsk, Belarus.

(date of receiving: September, 2020; date of acceptance: November, 2020)

\begin{abstract}
The article is focused on temporal lexical cycles in Russian - groups of words united by semantic relations of sequence and recurrence. Semantic and pragmatic properties of names-constituents of the day (утро-день-вечер-ночь), week (понедельник-вторниксреда-четверг-пятница-суббота-воскресенье), sеason (весна-лето-осень-зима) and уеат (январь-февраль-март-апрель-май-июнь-июль-авгукст-сентябрь-октябрьноябрь-декабрь) lexical cycles in Russian which become evident in the course of lexicographic, contextual, derivational and phraseological analysis, testify to the heterogeneity of the cyclical structures (e.g. natural, event-based and conventional ones; terminological/non-terminological: with rigid/non-rigid boundaries, etc.). Most significant is the salience of some member elements within the cycle (ночь 'night' in the day cycle, лето 'summer', весна 'spring' in the seasonal cycle, etc.). Knowledge of ontological features of the time period named, of activity related to it and subjectiveevaluative associations' language users may have on the basis of this information function as the foundation of the salience of cyclical members.
\end{abstract}

Key words: Temporal Lexical Cycle, Sequence, Recurrence, Salience, Frequency.

1. E-mail: zkharitonchik@mail.ru

2. E-mail: corbatan@ rambler.ru 


\title{
Лексические циклы в современном русском языке
}

\section{Харитончик Зинаида Андреевна ${ }^{1}$}

Профессор Минского государственного лингвистического университета,

$$
\text { Минск, Беларусь }
$$

\section{Корбачева Татьяна Валерьевна ${ }^{2}$}

Аспирант кафедры общего языкознания

Минского государственного лингвистического университета,

$$
\text { Минск, Беларусь }
$$

(дата получения: сентябрь 2020 г.; дата принятия: ноябрь 2020 г.)

\begin{abstract}
Аннотация
В статье рассматриваются темпоральные лексические циклы в современном русском языке - объединения лексических единиц, связанных семантическими отношениями последовательности и повторяемости. Языковые данные о семантических и прагматических свойствах наименований конституентов суточного (утро-день-вечер-ночь), недельного (понедельник-вторник-среда-четверг-пятницасуббота-воскресенье), сезонного (весна-лето-осень-зима) и годового (январьфевраль-март-апрель-май-июнь-июль-авгукст-сентябрь-октябрь-ноябрь-декабрь) циклов в русском языке, полученные в результате анализа лексикографических описаний, контекстуальных употреблений, дериватов и фразеологических единиц разного типа, образованных на их базе, свидетельствуют о неоднородности циклических объединений (напр., природные, событийные, конвенциональные; терминологические. нетерминологические; с жесткими/нежесткими границами и т.д.). Главное, они демонстрируют выделенность (салиентность) некоторых их членов (ночь в суточном цикле, лето, весна в сезонном и т.д.), в основе которой лежат знания об онтологических свойствах называемых временных периодов, о связанной с ними деятельности, а также субъективно-оценочные ассоциации, сложившиеся на базе этих знаний, у носителей языка.
\end{abstract}

Ключевые слова: Темпоральный Лексический Цикл, Последовательность, Повторяемость, Салиентность, Частотность.

1. E-mail: zkharitonchik@mail.ru

2. E-mail: corbatan@ rambler.ru 


\section{Введение}

Благодаря значительным успехам в исследовании закономерностей организации лексикона последние десятилетия ознаменовались переключением внимания лингвистов с уже получивших детальное описание глобальных типов семантических отношений, в первую очередь, гиперогипонимических и партономических (Никитин 2007. 357-393), на менее изученные типы семантических связей и формируемых ими лексических объединений. Одним из важнейших открытий исследований семантической организации лексики стало то, что порядок следования, являясь основополагающим принципом в синтагматике, играет значимую роль и в организации лексических единиц на парадигматическом уровне. Более глубокий анализ объединений слов, которым присущ этот тип отношений, позволил выявить их неоднородность, о чем свидетельствует наблюдаемое в лингвистической литературе терминологическое разнообразие: серийные последовательности (Miller 1976. 421), простые, линейные или одномерные поля (Coseriu 1981. 219), неветвящиеся иерархии (Cruse 1986. 181), линейные структуры (Cruse 2000. 189) и т.д.

Наиболее ярким примером языковых семантических объединений, в основе которых лежит последовательная организация их конституентов, несомненно, являются лексические циклы, репрезентирующие циклические структуры в обществе, природе, деятельности и т.д. Единицы в них связаны отношениями следования и повторяемости. Отражая динамику движения в определенном порядке и направлении, лексические циклы принадлежат категории времени, призванной дать некоторую количественную характеристику длительности бытия объектов, процессов и самого человека на бесконечности временного континуума и отражающей его определенные точки или периоды. Базируясь на наблюдениях за явлениями природы (например, сменой освещенных и не освещенных Солнцем промежутков времени, сменой сезонов и др.), на 
закономерностях, которые легли в основу сложной системы измерения времени, лексические циклические подсистемы не универсальны. В каждой культуре и, соответственно, в каждом языке вырабатывается свое видение членения времени, отвечающее запросам общества.

Циклическая последовательность, в языковой системе предстающая как лексический цикл, является, по мнению лингвистов, семантической таксономией особого типа (Leech 1970. 113), а для обозначения образующих такую совокупность элементов используется термин циклические имена. Структурная особенность циклических таксономий заключается в особом типе семантических отношений между ее элементами - циклических отношениях, которые, как указывалось ранее, подразумевают очередность следования и повторяемость.

\section{Цели, задачи, гипотеза и материал исследования}

Особенности отношений в лексических циклах находят отражение в семантике их конституентов. Как утверждает Дж. Лич, значения циклических имен «выводятся из положения, которое они занимают в достаточно сложной системе счета времени, сложившейся в западном обществе» (Leech 1970. 113). Исследователи обращают внимание на релятивность и повторяемость как важнейшие компоненты семантики циклических имен. Так, Э. Косериу говорит о том, что четверги являются особыми днями (черта, характерная не только им) благодаря тому, что находятся между средами и пятницами в определенной серии дней, которая называется неделей, и понимаются исключительно относительно этого положения (Coseriu 1981.237). Р. Джакендофф, объясняя, что́ делает вторник определенным днем, отмечает не только релятивность его положения в цикле (вторник следует за понедельником и предшествует среде), но отдельно подчеркивает его регулярную повторяемость. (Jackendoff 2012. 27) 
Существенным свойством лексических циклов, составляющим их коренное отличие от цепей, Дж. Н. Лич называет отсутствие первых и последних элементов в последовательностях (Leech 1974.115). Отметим, что первый и, соответственно, последний члены цикла могут быть результатом принятых в обществе конвенций. Однако, как поясняет Дж. Лайонз, «факт существования конвенционально установленных первых и последних членов во многих таких группировках (январь - это первый месяц года, а суббота - это последний день недели и т.д.) не нарушает их цикличности: Джон приехал в субботу, а Питер - на следующий день предполагает, что Питер приехал в воскресенье. Высказывание Джсн приехал в понедельник, а Питер - накануне имплицирует, что Питер приехал в воскресенье» (Lyons 1987. 290). Заметим также, что конвенциональные начало и конец одного и того же цикла могут различаться как в разных языках, так и в одном и том же языковом коллективе на разных культурно-исторических этапах его развития.

Способность членов лексического цикла объединяться в бесконечно повторяющийся замкнутый ряд вытекает из еще одной их отличительной особенности, на которую обращают внимание Дж. Лайонз и Д. А. Круз. Эта особенность заключается в том, что последовательность конвенциональна, т.е. не строится на степени проявления некоего салиентного признака. Нет такого признака Х, из-за которого вторник больше Х, чем понедельник, или февраль больше X, чем январь [Cruse 2000. 189; Lyons 1987. 290]. В данном случае не отрицается возможность выделения определенных интервалов времени на основании каких-то объективных признаков, но указывается, что более важным представляется именно занимаемое место в последовательности. Резюмируя рассуждения ученых об организации лексических циклов, перечислим выделяемые свойства лексической циклической подсистемы и ее конституентов: 
1) лексический цикл представляет собой линейную структуру закрытого типа, т.е. включает фиксированное количество языковых единиц;

2) конституенты лексических циклов связаны отношениями последовательности; последовательность ингерентна, т.е. изначально заложена в значениях единиц цикла;

3) замкнутый ряд членов лексического цикла бесконечно повторяется, т.е. отношениями последовательности связаны все члены цикла (в т. ч. конвенционально установленные последний и первый элементы);

4) отсутствует какой-либо салиентный признак, на степени проявления которого последовательность строится.

Вышесказанное имплицирует «равноправие», или равнозначность элементов цикла. Наиболее четко, на наш взгляд, эта мысль выражена Э. Косериу, который подчеркивает, что конституенты лексических циклов обозначают именно и исключительно положение в фиксированной серии (Coseriu 1981. 238). Действительно, можно привести не один пример, когда использование в высказывании того или иного циклического имени для представления некоторого промежутка времени определяется исключительно его положением в соответствующем цикле, как об этом свидетельствуют следующие контексты из Национального корпуса русского языка (НКРЯ):

Если непогодится, то март в Карпатах - как ноябрь. В Москве зимы настоящей нет, поэтому зимнюю одежду никто не носит.

Очевидно, что с именем каждого названного месяца и сезона ассоциируются некоторые погодные условия. Однако несоответствие реальных природных проявлений некоему идеализированному представлению о временном периоде, тем не менее, игнорируется, и предпочтение отдается позиционному признаку - месту в цикле. Говорящему необходимо отнести 
промежуток времени к той или иной категории, представленной в языке определенной временной номинацией. И в процессе категоризации (т.е. в процессе выбора циклической единицы) он ориентируется на наиболее существенный признак категории, за который принимается положение в циклической последовательности, а не возможные качественные модификации. Однако здесь встает вопрос о статусе и месте иных признаков, которые, как видно из примеров, также ассоциируются с конституентами лексического цикла.

Последнее подводит нас к выводу о том, что описание кардинальных черт лексических циклов (последовательности и повторяемости) не исчерпывает всей сложности семантических отношений конституентов внутри лексического циклического поля. Очевидно, например, что наряду с отношениями последовательности, позволяющими выражать значение каждого элемента как «идущий перед» или «следующий за» (Miller 1976. 422), членам ряда лексических циклов присущи также отношения полярной относительной оппозиции (Leech 1974. 115)). Ср. антонимические пары рус. лето-зима, весна-осень, утро-вечер, день-ночь (Львов 1984), что сигнализирует, по нашему мнению, об укорененности отношений противопоставленности между элементами суточного и сезонного циклов.

На этом фоне становится явной необходимость дальнейшего анализа отношений в лексических циклах, который позволит, по нашему мнению, раскрыть глубинные отношения между их конституентами.

Исходной гипотезой предпринимаемого нами анализа является мысль о том, что временная равнозначность, вытекающая из последовательности и повторяемости как основополагающих для темпоральных лексических циклов свойств, не является единственным принципом, определяющим место каждой конкретной единицы в лексическом цикле. Наличие серии хранящихся в сознании людей ассоциаций, которые обогащают семантику элементов лексических циклов прагматическими смыслами, определяя различия в их 
частотности и деривационной активности, позволяют предположить существование салиентности, или выделенности, детерминирующей неравнозначность как еще один тип отношений в лексическом цикле. Материал исследования составляют темпоральные циклические подсистемы русского языка, извлеченные путем сплошного просмотра из Большого толкового словаря русского языка под ред. С. А. Кузнецова (Большой толковый словарь 2000). При этом важно подчеркнуть, что в материал (76 лексических единиц) вошли только те наименования, в семантике которых представлены оба признака: и [+ПОСЛЕДОВАТЕЛЬНОСТЬ], и [+ПОВТОРЯЕМОСТЬ]. Отсутствием признака [-ПОВТОРЯЕМОСТЬ]) от них отличаются лексические последовательности, фиксирующие в языке ограниченный во времени срок жизни отдельных предметов или живых существ и содержащие в семантике своих членов только признак [+ПОСЛЕДОВАТЕЛЬНОСТЬ]. Таковы, например, наименования этапов жизни человека: младенчество, детство, отрочество, юность, зрелость, cmapocms; или периоды в жизни дерева как последовательности его возрастных состояний: росток - саженеи (маленькое юное деревце) - более взрослое дерево - дерево в расивете - старое дерево - мертвое (засохшее или сгнившее) (Кошелев 2015. 190) и др. В отличие от них темпоральные лексические циклы репрезентируют течение времени, топологическим свойством которого является незамкнутость, неограниченность, так как у времени нет ни начала, ни конца, и являются материальным воплощением наивного представления о течении времени как о периодически повторяющейся последовательности явлений и событий.

\section{Основная часть}

В качестве первого наблюдения над выделенными лексическими циклами следует отметить, что они являются частью холо-меронимических структур, в 
которых холоним (например, сутки, год и т.д.) функционирует как общее название лексического цикла, не входя в состав его членов. На отражение холо-меронимических отношений полностью ориентированы лексикографические описания семантики конституентов лексических циклов. В них элемент лексического цикла предстает как некоторая часть называемого общего отрезка времени. Например, день - часть суток от восхода до захода солнияа, от утра до вечера, понедельник - первый (после воскресенья) день недели, и т.д. Таким образом лексические циклы никоим образом не абсолютно автономны в языковом лексиконе, но включаясь в ведущие семантические связи лексических единиц, составляют важную, но своеобразную их подсистему.

Еще одним наблюдением, полученным в результате проведенного исследования, стал вывод о многоликости темпоральных лексических циклов в русском языке. Темпоральные лексические циклы включают наряду с первичными и наиболее значимыми лексическими циклами, такими как: наименования суточного, недельного, сезонного, годового циклов также наименования лунного цикла (новолуние, полнолуние,), суточного цикла положений солнца и освещенности небосвода (сумерки, рассвет, заря, восход, полдень, заход, закат, полночь), годового цикла астрономических явлений (равноденствие, солнцестояние).

Естественно, что в лексике русского языка находят выражение и культурно и социально значимые временные периоды или события, представляющие собой временные повторяющиеся последовательности. Это в первую очередь номинации религиозных и бытовых циклов, например, годовой литургический цикл, в котором течение времени представляется как периодически повторяющийся круг религиозных праздников и памятных дат (Рождество, Крещение, Сретение, Благовещчение, Успение и т. п.), суточный цикл богослужений (вечерня - утреня - обедня) и др. 
Становится, однако, очевидным, что темпоральные лексические циклы в русском языке, репрезентирующие разные циклические структуры, неоднородны по целому ряду характеристик. Так, широко представленные в русском языке религиозные темпоральные лексические циклы являются по своей сути некоторой достаточно разветвленной терминологической подсистемой обозначений специфической области в жизни общества. Очевидно также и то, что эта терминологическая подсистема ориентирована на уже сложившиеся временные периоды (день, сутки, месяц, год) и является таким образом вторичной системой, производной по своему характеру от базисных, первичных суточного, недельного, сезонного, годового лексических циклов. Будучи, без сомнения, интересными для языковедов (см., например, (Толстая 2005)), терминологические лексические циклы, фиксирующие цикличность явлений, процессов и т.д. в самых разных областях, составляют, на наш взгляд, отдельное поле исследований.

Различаются темпоральные лексические циклы и по линии принадлежности к ядру или периферии лексической системы языка. Ядро системы темпоральных лексических циклов в русском языке образуют циклы, конституентам которых свойственна эксплицитная цикличность, т.е. признаки последовательности и повторяемости находят выражение в значениях циклических единиц. Эта группа немногочисленна и включает ранее названные четыре цикла: суточный, недельный, сезонный и годовой. В периферию системы темпоральных циклов входят циклы, конституентам которых свойственна имплицитная цикличность. У таких лексических единиц цикличность выявляется при анализе словарных описаний других циклических имен. Так, в дефинициях лексем день и ночь в качестве рубежных точек указаны восход и заход: день - часть суток от восхода до захода солниа, ночь - часть суток от захода до восхода солнца. Отделяя временные периоды, сами пограничные зоны также обладают характерными для циклов свойствами 
временной соотнесенности, последовательности и повторяемости. В словарных описаниях языковых единиц, представляющих подобные рубежные моменты, не всегда указанные свойства представлены в полном объеме (например, у слов восход и заход место в последовательности не отражено: восход - появление над горизонтом небесного светила (утренней зари), заход - закат (небесного светила)). В периферию системы темпоральных лексических циклов входят суточный цикл положений солнца и освещенности небосклона, годовой цикл астрономических явлений, суточный цикл приема пищи, суточный цикл богослужений, годовой литургический цикл и т.д.

Важной отличительной характеристикой темпоральных лексических циклов являются онтологические основания градуирования составляющих их временных периодов, согласно которым циклы подразделяются на природные, основанные на наблюдениях за динамикой природных явлений, например, положения солнца или формы луны, событийные, отражающие последовательные и повторяющиеся этапы деятельности в жизни человека, общества) и конвенциональные (базирующиеся на условно принятых системах членения временного континуума (недельный и годовой лексические циклы). Естественно, что в зависимости от онтологических оснований темпоральные лексические циклы не совпадают по своему составу, включая от 2-4 (наименования членов суточного цикла день - ночь, или утро-день-вечерночь) до 12 компонентов (наименования членов годового цикла) и более (в годовом литургическом цикле).

Помимо количественных различий в темпоральных лексических циклах очевидны также различия по протяженности обозначаемых временных отрезков: (от нескольких часов (утро-день-вечер-ночь) до длительных периодов времени (сезонный цикл), а также по жесткости/ диффузности границ между периодами времени, обозначаемыми компонентами темпорального лексического цикла. Ср., например, названия частей суточного 
цикла, протяженность которых меняется в соответствии с сезонными колебаниями времени наступления пограничных точек между ними.

Картина семантических отношений внутри лексических циклов осложняется тем, что эти отношения не ограничиваются отношениями последовательности и повторяемости. Так, в суточном цикле помимо позиционно-релятивных семантических признаков темпоральных номинаций существенными являются также световые характеристики называемых временных отрезков, а в сезонном цикле - температурные характеристики, на основании которых складываются разнообразные отношения между конституентами внутри циклов. Например, в суточном лексическом цикле компоненты день и ночь оказываются противопоставленными по признаку наличие / отсутствие солнечного света, в то время как другие два компонента этого же цикла утро и вечер обладают, с одной стороны, сходными характеристиками, репрезентируя переходные периоды между освещенной и неосвещенной солнцем частями суточного цикла. С другой стороны, они отличаются вектором световых изменений (утро: неосвещенный $\rightarrow$ освещенный солнечным светом, вечер: освещенный $\rightarrow$ неосвещенный солнечным светом). Схожим образом взаимосвязаны лексические единицы сезонного цикла, где два компонента лето и зима противопоставляются по температурным характеристикам (самый теплый и самый холодный периоды), другие же два компонента весна и осень демонстрируют схожие свойства в том, что представляют переходные периоды, но отличаются вектором температурных изменений (весна: самый холодный $\rightarrow$ самый теплый, осень: самый теплый $\rightarrow$ самый холодный).

Если сложный характер отношений, не ограничиваемый отношениями последовательности и повторяемости, между конституентами лексических темпоральных циклов, отражающих ритмические природные изменения, можно считать закономерным, то в конвенциональных циклах, в которых, как 
указывалось ранее, главным принципом деления временного континуума является стремление к выделению равных / приблизительно равных временных периодов, сочетание циклических с иными типами отношений менее ожидаемо. Тем не менее даже в конвенциональных темпоральных лексических циклах наблюдается определенное неравноправие формирующих их элементов. Так, в лексикографических описаниях их значений, в которых на первом плане отражена релятивность их отношений (понедельник - первый (после воскресенья) день недели, январь - первый месяи календарного года, февраль - второй месяц календарного года и т.д.), присутствуют указания на соотнесенность месяцев года с сезонами, а отдельных дней недели (суббота, воскресенье) с событиями религиозного и деятельностного характера. Ср.: январь - первый месяц календарного года; второй месяи зимы, февраль второй месяи календарного года; последний месяи зимы и т.д..

Еще более разветвленную сеть семантических взаимосвязей и соответственно выделенность тех или иных компонентов темпоральных лексических циклов диктует разнообразие путей их концептуализации, которое выявляется при обращении к их прагматическим свойствам. На базе языковых данных, полученных в результате анализа связанной и свободной сочетаемости членов темпоральных лексических циклов, образованных от них дериватов, становится ясным, что в латентных семантических зонах компонентов темпоральных лексических циклов скрывается разноплановая информация, включающая знание, во-первых, об онтологических свойства денотатов, о деятельности, связанной с обозначаемым временным периодом, во-вторых, и субъективно-эмоциональная оценка, в-третьих.

Так, у элементов суточного темпорального лексического цикла выделяются определенные цветовые ассоциации. Например, день ассоциируется с белым цветом, а ночь - с черным: По какой-то совершенно непонятной зрительной ассоциаџии я безошибочно узнавал никогда раньше мною не виденнье города, 
над которыми первыц раз в жизни летел в обществе моих молчаливых ангелов: одного черного, как ночь, другого белого, как день. Для элементов утро и вечер характерна полихромность. Конституенту утро свойственен широкий диапазон цветовых ассоциаций: утро белесое, белое, бледное, бледно-лиловое, розовое, румяное, светлое, седое, серое, голубое, синее, тускло-белесоватое, розовое, румяное, лазурное, лиловое, золотистое, золотое, изумрудное. У конституента вечер ассоциативный цветовой спектр значительно уже и ограничивается желто-красным и сине-голубым диапазоном: вечер альй, багровый, багряный, золотой, красный, оранжевый, пасмурно-багровый, синий, снежно-голубой.

Источником природных ассоциаций в суточном цикле являются, помимо онтологических свойств денотатов, физиологические возможности человека воспринимать внешний мир в данных природных условиях. Способность ясно различать объекты при свете дня представляется базовым признаком, на который опираются носители языка при концептуализации элемента цикла день. Отсутствующее или ограниченное освещение в ночной период (категориальный признак конституента ночь), значительно снижающее зрительные возможности человека, выступает основой концептуализации слова ночь. Актуализация семантических признаков «видимость», «открытость, «публичность», «очевидность» у лексической единицы день и противоположных семантических признаков «ограниченная видимость», «неясность», «скрытность» у лексической единицы ночь эксплицируется в следующих контекстах: Он настаивает, что традищия проявляется как день u ночь - $к а к \quad$ зримая $и$ как незримая...; Всё же ясно как день! Тут и объяснять-то нечего!; Темны, как ночь, цъвганские дела...

Так же как и в суточном цикле, в концептуальных структурах наименований времен года, наряду с категориальными природными 
признаками (температурными характеристиками, зафиксированными в основных значениях лексем зима и лето), отражены результаты наблюдений за разными природными явлениями, свойственными для того или иного сезона, вегетационными процессами, физиологическими, поведенческими, миграционными особенностями представителей мира животных, видами деятельности человека и т.д. См. подробнее (Харитончик 2015).

Несмотря на то, что деление годового цикла на 12 месяцев представляет собой искусственно созданную систему, сформировавшуюся без учета какихлибо ритмичных процессов в окружающей среде, в латентной зоне семантики названий месяцев года тем не менее отражена разнообразная информация о природных явлениях, характерных для того или иного периода, таких, например, как: температура, типичные атмосферные явления, характер осадков. Ср.: ноябрь ледяной; Дьишал ноябрь осенним хладом; Пройдут нудные декабрь и январь, самые холодные месяџы зимы; У февраля два друга-метель и вьюга; жгучий жар июля; зноен, как июль и т.п. Актуализируется в многочисленных употреблениях названий месяцев и знание о продолжительности дневного периода, на основании которого особо выделяются месяцы, когда дневной период короче или, напротив, длиннее всего, о солнечной интенсивности, вегетативных процессах, поведенческих особенностях представителей мира фауны и т.д. и т.п.,

Важный источник концептуализации темпоральных циклических номинаций - деятельность человека, связанная с определенным временным периодом. На этом основании формируются ассоциации с названиями суточного цикла, в семантике которых находит отражение организация жизни и деятельности человека, построенная с учетом суточных биологических ритмов организма - активность в светлый, дневной период времени, отдых и сон в темный, ночной период времени. Например: День государев, а ночь наша; День пришел, так и есть принес; день прошел, заботу унес; День в грехе, а ночь во сне. 
Сельскохозяйственная деятельность и общая организация труда, чередование периодов труда и отдыха выступают релевантными признаками при характеризации конституентов сезонного и 12-месячного годового циклов. Собьет июль с мужика спесь, коли некогда присесть; Июль устали не знает, все прибирает; В августе мужику три заботы: и косить, и пахать, и сеять; Какое лето без отдыха!.

На базе природных и деятельностных характеристик конституентов темпоральных лексических циклов формируются их субъективно-оценочные семантические признаки. Так, в сезонном цикле узкий цветовой диапазон, низкие температурные показатели в зимнее время имплицируют такие оценочные ассоциации у номинации зима, как строгость и сдержанность, а многоцветье, тепло, комфортные погодные условия летом вызывают ассоциации красоты, нежности и т.п., например, Но как лето и зима вдруг быть не могут, чтобы вы, сличив одно с другим, при строгости и скучном виде одного могли яснее видеть и выше почесть другого красоту, нежность и приятность; Ax, строгая зима! Tbl чудо-щеголиха... Начало нового жизненного цикла в мире природы, обильное цветение деревьев и трав, гнездование птиц и т.п. в весенний период порождают такие эмоциональнооценочные характеристики конституента весна, как красота, веселье, радость, эмоциональный подъем, пора любви, например, ее сестра хороша, как весна; Весна - пора любви; Матюшин - весел, как весна; ... на улицах показывались оживленные, свежие лица, такие же молодые и радостные, как весна. Осень, которой свойственны листопад, затяжные дожди, похолодание, в русской языковой картине мира наделяется такими эмоционально-оценочными признаками: грусть, печаль, скука. Например: Форточка была открыта и в нее, вместе со свежим тепльм воздухом, лилась отголоски широкой хоровой песни, грустной как осень.... 
Среди названий месяцев ноябрь сопровождается негативной эмоциональной оценкой, актуализируемой в таких контекстах: ноябрь сльвет унылым, действующим на людей депрессивно или нервозно; В самый скучный месяц, в тусклом ноябре.

Выявленные семантические особенности конституентов темпоральных лексических циклов приводят к выводу о выделенности тех или иных элементов темпоральных лексических циклов в русском языке. Разная частотность формирующих лексические циклы единиц, отражающая функциональный вес каждой лексической единицы в цикле, - убедительное тому доказательство.

В суточном цикле явной выделенностью обладает элемент ночь, который по частотности своего употребления лидирует и в основном корпусе (37\%), и в поэтическом $(51,4 \%)$. Конституент день имеет наименьшие показатели (5\%) в общем корпусе, хотя в поэтическом корпусе занимает 2-е место $(21,3 \%)$.
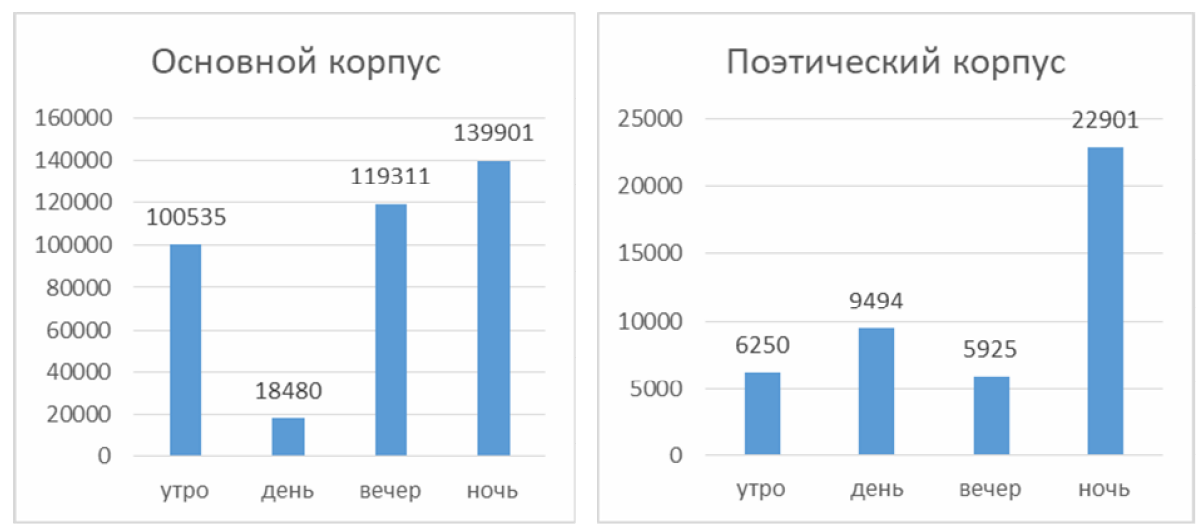

Частотное превосходство компонента ночь, особенно значительное в поэтическом корпусе, коррелирует с большим объемом семантических ассоциаций, связанных с этой единицей, причем многие из них несут дополнительную эмоциональную нагрузку, например, с ночью ассоциируются тишина, безмолвие, пустота, одиночество, страх, зло, нечистая сила и т.д. 
Анализ частоты употребления наименований конституентов недельного цикла также выявил значительные различия в их употребительности. Самые высокие показатели частотности имеет компонент лексического цикла воскресенье, который лидирует и в общем (24\%), и в поэтическом (36\%) подкорпусах. По параметру употребительности также выделяется компонент суббота. На третьем месте в общем корпусе находятся понедельник (14\%) и пятница (14\%). В поэтическом подкорпусе компоненты недельного цикла четверг (11\%), пятница (10\%), среда (8 \%), понедельник (7 \%), вторник (7 \%) относительно равноправны и имеют достаточно низкие показатели на фоне салиентных компонентов воскресенье (36 \%) и суббота $(21 \%)$.
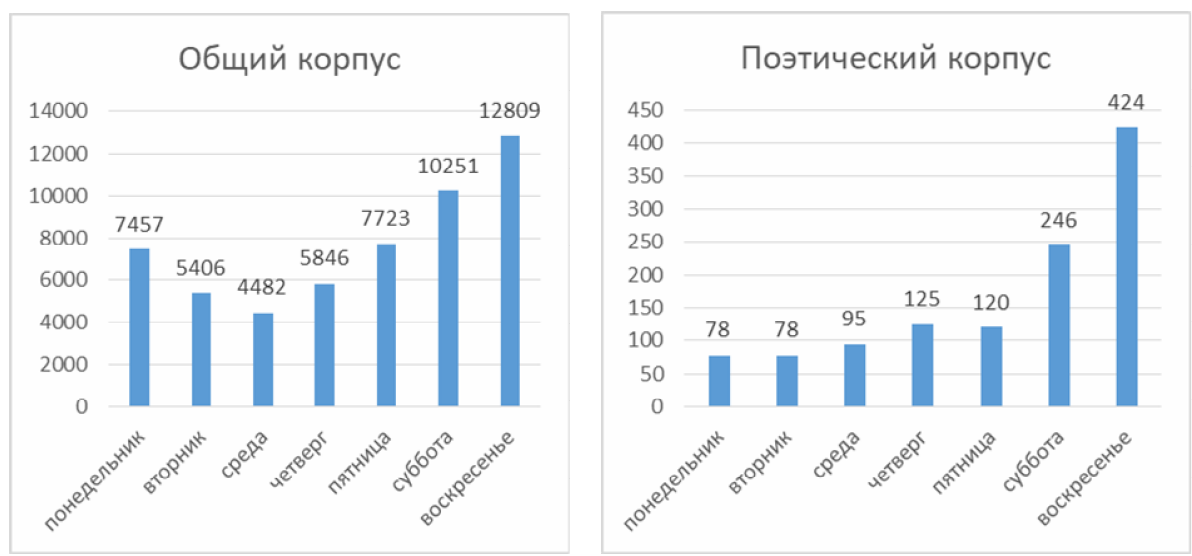

Количественная выделенность компонентов воскресенье и суббота соотносится с наличием у этих лексических единиц такого компонента значения как выходной день, и связанной с этим положительной эмоциональной оценкой. А понедельник и пятница, представляющие первый и последний рабочие дни и часто сопровождаемые в первом случае отрицательной, а во втором положительной эмоциональными оценками, по частотности выделяются на фоне названий других рабочих дней недели. 
Очевидна также неравнозначность употребления конституентов сезонного лексического цикла. При этом в сезонном лексическом цикле салиентные компоненты различаются по данным разных корпусов. Так, согласно данным основного корпуса наиболее значимым оказываются самый теплый, лето (34\%), и самый холодный, зима (26\%), периоды года. Менее частотными оказались обозначения переходных периодов весна (22\%) и осень (18\%). В поэтическом подкорпусе лидирует компонент весна (42\%).
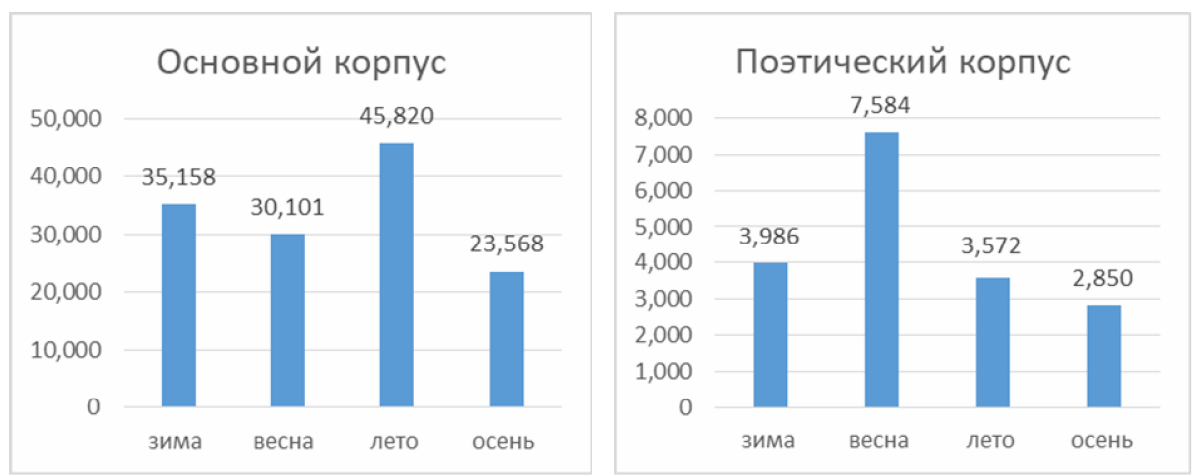

Среди конституентов годового лексического цикла наиболее частотными компонентами являются март (9,5 \%), май (10\%), август (10 \%).

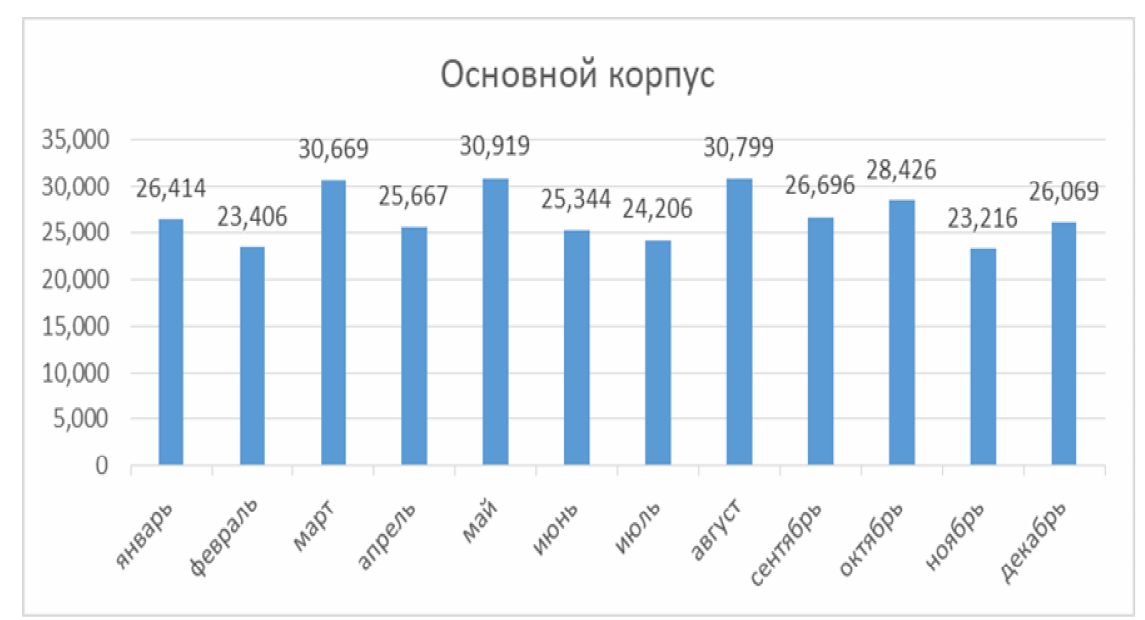


Однако по частотности употреблений наименований месяцев года в поэтическом корпусе НКРЯ выделяется явный лидер - май, обладая такими ассоциациями как юность, нежность, радость.

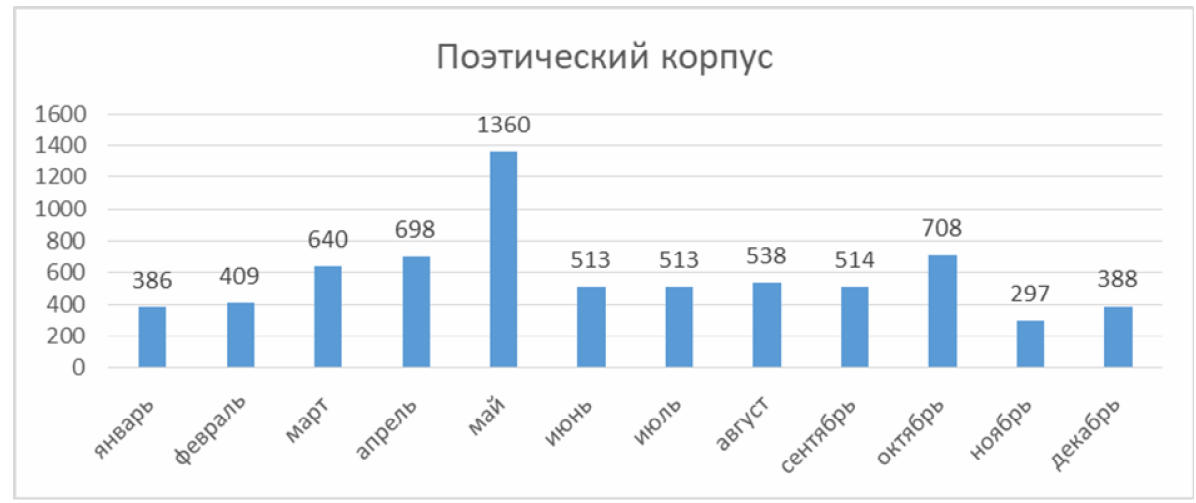

Таким образом, можно с уверенностью заключить, что высказанная нами ранее гипотеза о выделенности тех или иных компонентов темпоральных лексических циклов в русском языке получила свое подтверждение.

\section{Заключение}

Важнейшим принципом организации ядерных темпоральных лексических циклов как неотъемлемых таксономий лексической системы русского языка, называющих направленные на эффективную организацию жизнедеятельности общества циклические структуры, сложившиеся в русском языковом коллективе, является, несомненно, «равноправие» их конституентов. Это находит отражение в ведущих их категориальных семантических свойствах [+ПОСЛЕДОВАТЕЛЬНОСТЬ $]$ и [+ПОВТОРЯЕМОСТЬ $], \quad$ которЫмИ предопределяются традиции их лексикографического описания как релятивных имен. Многочисленные прагматические характеристики, формирующие латентную зону семантики конституентов темпоральных 
лексических циклов, которая актуализируется в свободных и связанных словосочетаниях, в образованных дериватах, детерминируют выделенность (салиентность) одних конституентов на фоне других и соответственно «неравноправие» как еще один принцип их функционирования. В качестве оснований салиентности единиц ядерных темпоральных лексических циклов в русском языке выступают знания об онтологических свойствах называемых временных периодов, о связанной с ними деятельности, эт а также субъективно-оценочные ассоциации, сложившиеся на базе их знаний, у носителей языка.

\section{ЛИТЕРАТУРА}

1- Большой толковый словарь русского языка (2000). Сост. и гл. ред. С. А. Кузнецов. -СПб.: Норинт.

2- Кошелев А. Д. (2015). Когнитивный анализ общечеловеческих концептов. М.: Рукописные памятники Древней Руси.

3- Львов М. Р. (1984). Словарь антонимов русского языка: Более 2000 антонимических пар. - Под ред. Л. А. Новикова. - 2-е изд., испр. и доп. -М.: Рус. яз.

4- Национальный корпус русского языка [Электронный ресурс]. - Режим доступа: htpp://www. ruscorpora.ru. - Дата доступа: 15.01.2020.

5- Никитин М. В. (2007). Курс лингвистической семантики. - 2-е изд. доп. и испр. -СПб.: Изд-во РГПУ им. А. И. Герцена.

6- Толстая С.М.(2005). Полесский народный календарь. -М.: Индрик,

7- Харитончик 3. А. (2015). Деривационная активность конституентов лексических циклических структур, В поисках сущности имен. Избранное: сб. науч. ст. - Минск: МГЛУ, 143-150.

8- Coseriu E. (1981). Principios de semántica estructural Versíon esp. de M. Martánez Hernández revisada por el autor - 2 a ed. - Madrid: Gredos.

9- Cruse D. A. (1986). Lexical semantics (Cambridge textbooks in linguistics) - New York: Cambridge University Press.

10- Cruse D. A. (2000). Meaning in Language. An Introduction to Semantics and Pragmatics. - New York: Oxford University Press. 
11- Jackendoff R. (2012). A user's guide to thought and meaning. - New York: Oxford University Press.

12- Leech G. N. (1970). Towards a Semantic Description of English. - Bloomington; London: Indiana University Press.

13- Leech G. N. (1974). Semantics. - London: Penguin.

14- Lyons J. (1987). Semantics. - 7th ed. Cambridge University Press.

15- Miller G. A. (1976). Language and perception / G. A. Miller, P. N. Johnson-Laird. - Cambridge, Massachusetts: Belknap Press of Harvard University Press.

\section{Bibliography}

1- Bol'shoj tolkovyj slovar' russkogo jazyka (2000). Sost. i gl. red. S. A. Kuznecov. $\mathrm{SPb}$.: Norint.

2- Koshelev A. D. (2015). Kognitivnyj analiz obshhechelovecheskih konceptov. - M.: Rukopisnye pamjatniki Drevnej Rusi.

3- L'vov M. R. (1984). Slovar' antonimov russkogo jazyka: Bolee 2000 antonimicheskih par. - Pod red. L. A. Novikova. - 2-e izd., ispr. i dop. -M.: Rus. jaz.

4- Nacional'nyj korpus russkogo jazyka [Jelektronnyj resurs]. - Rezhim dostupa: htpp://www. ruscorpora.ru. - Data dostupa: 15.01.2020.

5- Nikitin M. V. (2007). Kurs lingvisticheskoj semantiki. - 2-e izd. dop. i ispr. -SPb.: Izd-vo RGPU im. A. I. Gercena.

6- Tolstaja S.M.(2005). Polesskij narodnyj kalendar'. -M.: Indrik,

7- Haritonchik Z. A. (2015). Derivacionnaja aktivnost' konstituentov leksicheskih ciklicheskih struktur, V poiskah sushhnosti imen. Izbrannoe: sb. nauch. st. - Minsk: MGLU, 143-150.

8- Coseriu E. (1981). Principios de semántica estructural Versíon esp. de M. Martínez Hernández revisada por el autor - 2 a ed. - Madrid: Gredos.

9- Cruse D. A. (1986). Lexical semantics (Cambridge textbooks in linguistics) - New York: Cambridge University Press.

10- Cruse D. A. (2000). Meaning in Language. An Introduction to Semantics and Pragmatics. - New York: Oxford University Press.

11- Jackendoff R. (2012). A user's guide to thought and meaning. - New York: Oxford University Press.

12- Leech G. N. (1970). Towards a Semantic Description of English. - Bloomington; London: Indiana University Press.

13- Leech G. N. (1974). Semantics. - London: Penguin. 
14- Lyons J. (1987). Semantics. - 7th ed. Cambridge University Press.

15- Miller G. A. (1976). Language and perception / G. A. Miller, P. N. Johnson-Laird. - Cambridge, Massachusetts: Belknap Press of Harvard University Press.

HOW TO CITE THIS ARTICLE

Харитончик, 3., \& Корбачева, Т. (2021). Lexical Cycles in Modern Russian. Issledovatel'skiy Zhurnal Russkogo Yazyka I Literatury, 9(1). 43-66.

DOI: $10.52547 /$ iarll.17.43

URL: https://www.journaliarll.ir/index.php/iarll/article/view/147

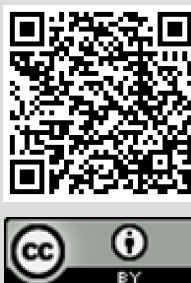




$$
\begin{aligned}
& \text { جرخههاى وازگانى در زبان روسى معاصر }
\end{aligned}
$$

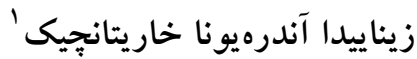

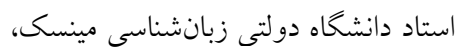

$$
\begin{aligned}
& \text { مينسك، بلاروس. } \\
& \text { تاتيانا والرىيونا كارباجِوواج }
\end{aligned}
$$

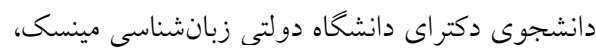

$$
\begin{aligned}
& \text { مينسك، بلاروس. }
\end{aligned}
$$

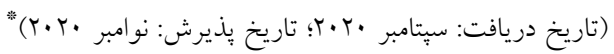

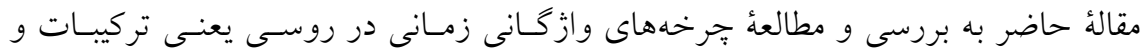

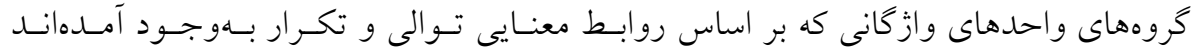

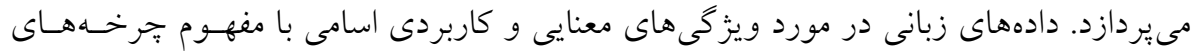

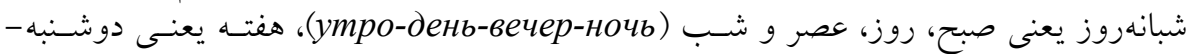

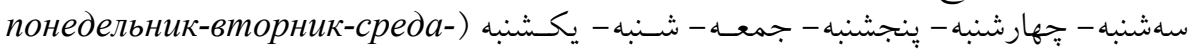
(четверг-пятница-суббота-воскресенье

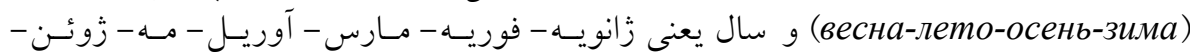

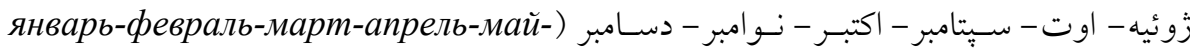
(июнь-июль-авгукст-сентябрь-октябрь-ноябрь-декабрь

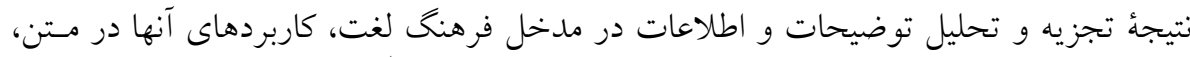

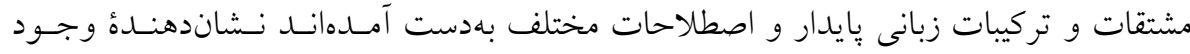

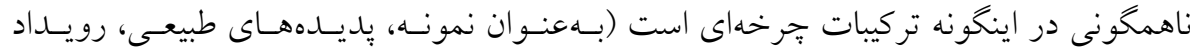

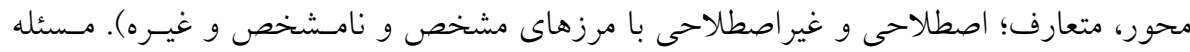

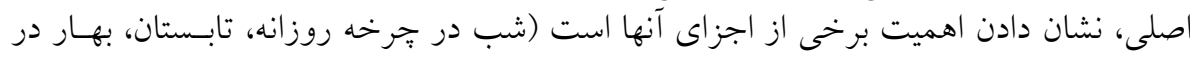

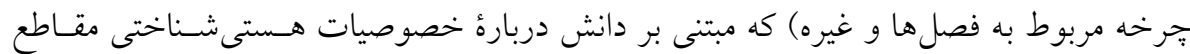

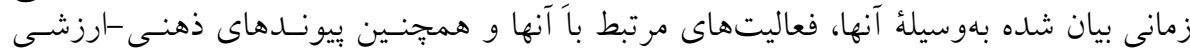

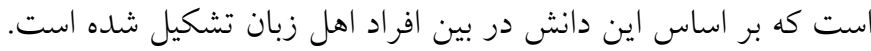

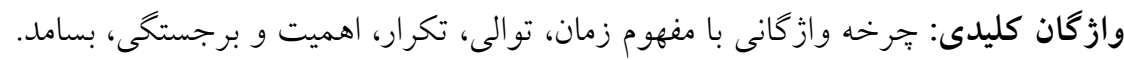

1. E-mail: zkharitonchik@mail.ru

2. E-mail: corbatan@ rambler.ru 